\title{
Rapid regulation of thyroid sodium-iodide symporter activity by thyrotrophin and iodine
}

\author{
Andrea C F Ferreira, Lívia P Lima, Renata L Araújo, \\ Glaucia Müller, Renata P Rocha, Doris Rosenthal and \\ Denise P Carvalho
}

Laboratório de Fisiologia Endócrina, Instituto de Biofísica Carlos Chagas Filho, Universidade Federal do Rio de Janeiro, Rio de Janeiro, Brazil

(Requests for offprints should be addressed to D P Carvalho, Instituto de Biofísica Carlos Chagas Filho, CCS-Bloco G, Cidade Universitária, Ilha do Fundão, Rio de Janeiro, 21949-900, Brasil; Email: dencarv@biof.ufrj.br)

\begin{abstract}
Transport of iodide into thyrocytes, a fundamental step in thyroid hormone biosynthesis, depends on the presence of the sodium-iodide symporter (NIS). The importance of the NIS for diagnosis and treatment of diseases has raised several questions about its physiological control. The goal of this study was to evaluate the influence of thyroid iodine content on NIS regulation by thyrotrophin (TSH) in vivo. We showed that 15-min thyroid radioiodine uptake can be a reliable measurement of NIS activity in vivo. The effect of TSH on the NIS was evaluated in rats treated with 1-methyl2-mercaptoimidazole (MMI; hypothyroid with high serum TSH concentrations) for 21 days, and after 1 (R1d), 2 (R2d), or 5 (R 5 d) days of withdrawal of MMI. NIS activity was significantly greater in both MMI and
\end{abstract}

$\mathrm{R} 1 \mathrm{~d}$ rats. In $\mathrm{R} 2 \mathrm{~d}$ and $\mathrm{R} 5 \mathrm{~d}$ groups, thyroid iodide uptake returned to normal values, despite continuing high serum TSH, possibly as a result of the re-establishment of iodine organification after withdrawal of MMI. Excess iodine $(0 \cdot 05 \% \mathrm{NaI}$ for 6 days $)$ promoted a significant reduction in thyroid radioiodide uptake, an effect that was blocked by concomitant administration of MMI, confirming previous findings that iodine organification is essential for the iodide transport blockade seen during iodine overload. Therefore, our data show that modulation of the thyroid NIS by TSH depends primarily on thyroid iodine content and, further, that the regulation of NIS activity is rapid.

Journal of Endocrinology (2005) 184, 69-76

\section{Introduction}

Thyroid hormones are implicated in the regulation of metabolism, growth and maturation of a variety of organ systems, and iodine is an essential component of their molecules (Taurog 2000). The transport of iodide into thyrocytes is fundamental for thyroid hormone biosynthesis and is catalysed by the sodium-iodide $\left(\mathrm{Na}^{+} / \mathrm{I}^{-}\right)$ symporter (NIS), an intrinsic basolateral membrane protein of these cells. NIS cDNA has been cloned, and further biochemical studies demonstrated that the protein transports one molecule of iodide together with two molecules of sodium into the intracellular compartment. Thus iodide transport is secondary to the sodium gradient formed by the $\mathrm{Na}^{+} / \mathrm{K}^{+}$-ATPase also present in the basolateral membrane of thyrocytes (Dai et al. 1996, Smanik et al. 1996, Eskandari et al. 1997, Dohan et al. 2001, 2003, Van Sande et al. 2003).

In addition to its key role in thyroid physiology, NIS-mediated accumulation of iodide within the thyroid gland is important in diagnostic procedures and for treatment of benign and malignant thyroid diseases (Heufelder et al. 2001, Chung 2002). Hence, NIS gene transfer is being used to express functionally active NIS in other cell types, a strategy that could extend the application of radioiodine to non-thyroid cancers (Spitzweg \& Morris 2001). The importance of NIS expression for the diagnosis and treatment of diseases has raised a series of questions about the mechanisms underlying the control of NIS expression, and the regulation of its activity in the plasma membrane.

The ability of the thyroid gland to concentrate iodine has been known for several decades and many reports have demonstrated that thyrotrophin (TSH), together with thyroid gland iodine content, regulates the transport of iodide into the thyroid. Fish et al. (1952) showed that the degree of thyroid uptake of iodine-131 is inversely related to the amount of iodine available in the gland. Later, it was shown that the rate-limiting step of thyroid accumulation of iodine by thyrocytes was iodide trapping, rather than its organic binding (Berson \& Yalow 1955). 
TSH stimulates expression of the NIS gene and increases iodide uptake by thyrocytes (Kaminsky et al. 1994, Riedel et al. 2001). Recently, the findings of several studies have indicated that NIS protein can be found in two distinct subcellular compartments: the plasma membrane and intracellular vesicles. The latter are considered to be a pool of NIS protein that could be rapidly mobilized to the cellular membrane by TSH and other as yet undefined mechanisms (Kaminsky et al. 1994, Dohan et al. 2001, Riedel et al. 2001, Tonacchera et al. 2002). The majority of studies on the regulation of thyroid iodide uptake by TSH were carried out in FRTL- 5 cells, which are unable to organify iodine efficiently. In vivo analyses could give a better understanding of the physiological modulation of NIS activity.

Exposure of thyroid cells to high concentrations of iodine in vitro and in vivo reduces iodide transport and its organification into proteins - the Wolff-Chaikoff effect (Wolff \& Chaikoff 1948, Price \& Sherwin 1986); this regulation of iodide transport is probably mediated by organic iodinated compounds, such as iodoaldehydes (Van Sande et al. 1985, Panneels et al. 1994, 1996). It is unlikely that mono-iodothyrosine, di-iodothyrosine, or iodothyronine act as inhibitors of iodide transport, because the quantity of newly formed iodinated amino acids does not correlate with the decreased thyroid:serum iodide concentration ratio (Socolow et al. 1968).

The autoregulation of thyroid function by iodine is transient, and thyroid cells escape from the effects of iodine overload after some days (Braverman \& Ingbar 1963). The adaptation to the inhibitory effects of large doses of iodine is probably an intrinsic thyroid mechanism: a decrease in thyroid iodide transport and therefore a decline in the intrathyroid iodine pool. Thus the decreased amount of thyroid iodine becomes insufficient to sustain the Wolff-Chaikoff effect (Braverman \& Ingbar 1963). A reduction in NIS mRNA has recently been shown to occur after iodine overload (Uyttersprot et al. 1997, Morand et al. 2003), and Eng et al. (1999) proposed that the significantly decreased levels of NIS mRNA and protein that occur 1 and 6 days after the administration of excess iodine to rats could be implicated in the mechanism of escape from the Wolff-Chaikoff effect. However, no further analysis of NIS functional activity has been made using this model.

The goal of the present study was to evaluate the modulation of thyroid iodide uptake by TSH under the influence of exposure to normal or increased iodine. We show here that, even in the presence of increased serum concentrations of TSH, NIS activity is significantly decreased by resumption of thyroid iodine organification in animals fed a normal iodine diet. Our findings demonstrate that thyroid iodine content, even under physiological conditions, seems to influence the TSH response negatively in terms of the ability of the thyroid to take up iodide.

\section{Materials and Methods}

\section{Materials}

L-Thyroxine $\left(\mathrm{T}_{4}\right)$ and 1-methyl-2-mercaptoimidazole (MMI) were from Sigma. Sodium iodide, Tris(hydroxymethyl)aminomethan, glucose and potassium iodide were from Merck (Rio de Janeiro, RJ, Brazil). Glucose oxidase (grade I) was purchased from Boehringer and iodine-125labelled $\mathrm{NaI}$ was purchased from Amersham.

\section{Animals}

Male adult Wistar rats weighing 250-300 g were housed under controlled conditions of temperature $\left(24 \pm 1{ }^{\circ} \mathrm{C}\right)$ and light (12 h light starting at $0700 \mathrm{~h}$ ) and all experiments were conducted in accordance with standards of animal care defined by the Institutional Committee.

\section{Short-term radioiodide uptake: NIS activity}

Measurements of thyroid radioiodine uptake are usually made 2, 24 or $72 \mathrm{~h}$ after the administration of radioiodine. However, immediately after iodide enters into thyrocytes it can be incorporated into proteins, and the measurement of radioactivity in the gland should thus correspond to both iodide transport and organification activities. In order to evaluate in vivo NIS activity using measurements of thyroid radioiodine uptake, free from the influence of a thyroid peroxidase (TPO) iodine organification reaction, MMI (5 mg intraperitoneally (i.p.)) or an equivalent volume of the solvent were administered to control animals $15 \mathrm{~min}$ before the administration of radioiodine. The animals received $\left[{ }^{125} \mathrm{I}\right] \mathrm{NaI}(3700 \mathrm{~Bq}$ i.p.) $15 \mathrm{~min}$ or $2 \mathrm{~h}$ before decapitation. The thyroid glands were removed and weighed and their radioactivity measured using a gamma counter (LKB) and expressed as percentage of total iodine-125 injected per mg of thyroid.

The 2-h measure of radioiodine uptake is believed to correspond to the entry of iodine through the NIS. However, as we show here, administration of MMI $15 \mathrm{~min}$ before radioiodide produces a significant decrease in thyroid radioiodine content (Fig. 1). In contrast, the measurement of thyroid uptake of radioiodide 15 min after its administration was unchanged by MMI (Fig. 1), showing that, after $15 \mathrm{~min}$ of iodide administration, the ion is not significantly incorporated into proteins. Thus we can consider 2-h thyroid radioiodine uptake to be mainly a measure of the organification reaction in vivo, and 15-min radioiodine uptake to be a valid estimation of iodide transport through the basolateral membrane.

\section{Effect of TSH on NIS activity}

Rats were divided into the following groups: control (water available ad libitum), MMI (0.03\% MMI in the 


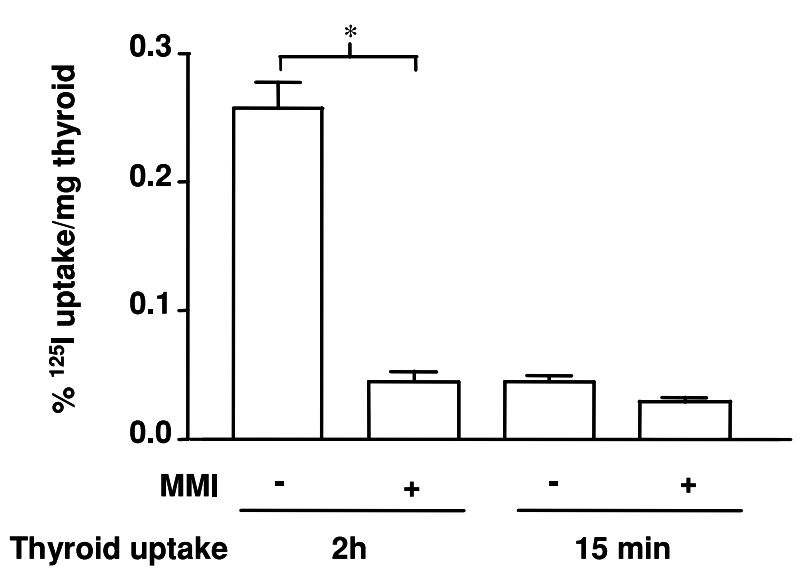

Figure 1 Thyroid iodide uptake $2 \mathrm{~h}$ or $15 \mathrm{~min}$ after administration of radioiodide. MMI ( $0.5 \mathrm{mg}$ i.p.) or an equivalent volume of the diluent was administered $15 \mathrm{~min}$ before the animals received $\left[{ }^{125} \mathrm{I}\right] \mathrm{Nal}(3700 \mathrm{~Bq}$ i.p.). After $2 \mathrm{~h}$ or $15 \mathrm{~min}$, the thyroids were removed and weighed, and the radioactivity was measured and expressed as percentage of the iodine-125 injected per mg thyroid (2-h control group, $n=14 ; 2$-h MMI group, $n=9 ; 15$-min control group, $n=18 ; 15-$ min MMI group, $n=8$ ). Results are expressed as the mean \pm S.E.M. of each group. ${ }^{*} P<0.05$ compared with $2 \mathrm{~h}$ without prior administration of MMI (unpaired t-test).

drinking water for 21 days), R1d (0.03\% MMI in the drinking water for 21 days, followed by 1 day without MMI), R2d (0.03\% MMI in the drinking water for 21 days, followed by 2 days without MMI) and R5d (0.03\% MMI in the drinking water for 21 days, followed by 5 days without MMI).

\section{Administration of iodine}

In order to evaluate the effects of iodide overload, we used a procedure that has previously been shown to increase serum iodide concentrations significantly and produce the Wolff-Chaikoff effect (Eng et al. 1999). Rats were divided into the following groups: control group (water available ad libitum), 1 day $\mathrm{NaI}(0 \cdot 05 \% \mathrm{NaI}$ in the drinking water for 1 day) and 6 days $\mathrm{NaI}(0.05 \% \mathrm{NaI}$ in the drinking water for 6 days). As the effects of iodide on thyroid function are probably mediated through an iodinated compound, we examined another group that received MMI in parallel with $\mathrm{NaI}$ and $\mathrm{T}_{4}\left[\mathrm{NaI}+\mathrm{MMI}+\mathrm{T}_{4}: 0 \cdot 05 \% \mathrm{NaI}\right.$ and $0.03 \% \mathrm{MMI}$ in the drinking water for 6 days and $1 \mu \mathrm{g}$ $\mathrm{T}_{4} / 100 \mathrm{~g}$ body weight (b.w.) subcutaneously (s.c.) for 5 days, starting 1 day after the beginning of treatment with MMI and NaI], to block thyroid iodine organification without changing the serum concentrations of TSH. As controls, one group received $0.03 \% \mathrm{MMI}$ in the drinking water for 6 days and $1 \mu \mathrm{g} \mathrm{T} / 100 \mathrm{~g}$ b.w. s.c. for 5 days, starting 1 day after the beginning of treatment with MMI $\left(\mathrm{MMI}+\mathrm{T}_{4}\right)$ and another received 0.03\% MMI alone in the drinking water for 6 days (MMI). Control animals received $2 \mathrm{mg} \mathrm{NaI}$ i.p. $1 \mathrm{~h}$ before administration of the radioiodide, to promote similar concentrations of cold serum iodide compared with NaI-treated animals (Eng et al. 1999). Groups MMI, and MMI $+\mathrm{T}_{4}$ and the control group did not receive an acute injection of $\mathrm{NaI}$.

\section{Hormone measurements}

Serum total $\mathrm{T}_{4}$ was assayed using commercial kits (Diagnostic Products Corporation, Los Angeles, CA, USA), and $\mathrm{T}_{4}$ standard curves were made with hormonefree rat serum. Serum TSH determination was performed with a specific RIA using primary antibodies for rat TSH. Rat TSH for iodination and preparation of the standard curve was provided by the National Hormone and Peptide Program/National Institute of Diabetes, Digestive and Kidney Diseases (Bethesda, MD, USA).

\section{Preparation of thyroperoxidase (TPO)}

Extraction of TPO from rat thyroids was performed as described previously (Moura et al. 1987). Pools of two rat thyroids were minced and homogenized in $0.5 \mathrm{ml} 50 \mathrm{mM}$ Tris- $\mathrm{HCl}$ buffer, $\mathrm{pH} 7 \cdot 2$, containing $1 \mathrm{mM} \mathrm{KI}$, using an Ultra-Turrax homogenizer (Staufen, Germany). The homogenate was centrifuged at $100000 \mathrm{~g}$ at $4{ }^{\circ} \mathrm{C}$ for $1 \mathrm{~h}$. The pellet was suspended in $0.5 \mathrm{ml}$ digitonin $(1 \% \mathrm{w} / \mathrm{v})$ and incubated at $4{ }^{\circ} \mathrm{C}$ for $24 \mathrm{~h}$ to solubilize the peroxidase. The digitonin-treated suspension was centrifuged at $100000 \mathrm{~g}$ at $4{ }^{\circ} \mathrm{C}$ for $1 \mathrm{~h}$, and the supernatant containing the solubilized TPO was used for the assays. Protein content was determined by the method of Bradford (1976).

\section{TPO activity}

The TPO iodide-oxidation activity was measured as described previously (Nakashima \& Taurog 1978, Pommier 1978, Moura et al. 1987, 1989, Carvalho et al. 1994). The assay mixture contained $1.0 \mathrm{ml}$ freshly prepared $50 \mathrm{mM}$ sodium phosphate buffer, $\mathrm{pH} 7 \cdot 4$, containing $24 \mathrm{mM} \mathrm{KI}$ and $11 \mathrm{mM}$ glucose, and increasing amounts of solubilized TPO. The final volume was adjusted to $2 \cdot 0 \mathrm{ml}$ with $50 \mathrm{mM}$ sodium phosphate buffer, $\mathrm{pH} 7 \cdot 4$, and the reaction was started by the addition of $10 \mu \mathrm{l} \quad 0 \cdot 1 \%$ glucose oxidase (Boehringer grade I). The increase in absorbance at $353 \mathrm{~nm}$ (tri-iodide production) was registered for $4 \mathrm{~min}$ on a Hitachi spectrophotometer (U-3300). The change in $\mathrm{A}_{353 \mathrm{~nm}} / \mathrm{min}$ was determined from the linear portion of the reaction curve and related to protein concentration and the results expressed as $\mathrm{U} / \mathrm{g}$ protein.

\section{Statistical analysis}

All the experiments were repeated at least three times, using at least five animals per group in each experiment. 
Table 1 Serum total $\mathrm{T}_{4}$ and TSH concentrations (mean \pm S.E.M.) in rats treated with $\mathrm{MMI}$ for 21 days and after its removal for different periods of time ( $1-5$ days)

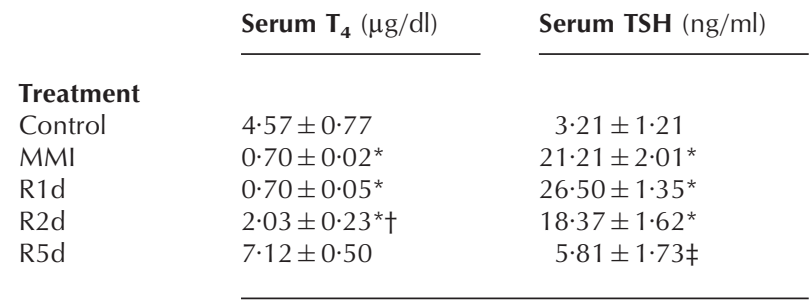

Control, water available ad libitum; MMI, 0.03\% MMI in the drinking water for 21 days; R1d, $0.03 \% \mathrm{MMI}$ in the drinking water for 21 days, followed by 1 day without MMl; R2d, $0.03 \% \mathrm{MMI}$ in the drinking water for 21 days, followed by 2 days without $\mathrm{MMl}$; R5d, $0.03 \% \mathrm{MMI}$ in the drinking water for 21 days, followed by 5 days without MMI.

Significantly different values $(P<0 \cdot 05)$ compared with: *control and R5d; †MMI and R1d; ‡control, MMI, R1d and R2d.

Results are expressed as mean \pm S.E.M. and were analysed by unpaired $t$-test or one-way analysis of variance (ANOVA), followed by the Newman-Keuls multiple comparison test. After logarithmic transformation, serum TSH concentrations were analysed by one-way ANOVA, followed by the Newman-Keuls multiple comparison test and are expressed as arithmetic means \pm S.E.M. TPO activity was analysed by Kruskal-Wallis analysis of variance followed by Dunn tests.

\section{Results}

\section{Regulation of NIS activity by TSH}

Serum $\mathrm{T}_{4}$ was significantly lower in rats that received MMI for 21 days and in animals from which MMI was removed 1 (R1d) or 2 days (R2d) before they were killed; serum TSH concentrations were also significantly greater in these three groups of animals. After 5 days of MMI withdrawal (R5d), serum $\mathrm{T}_{4}$ had already reached concentrations that were not statistically different from those of control animals, but TSH remained increased (Table 1).

As a result of increased TSH, rats treated with MMI for 21 days had significantly greater 15-min thyroid iodide uptake than did the control group (Fig. 2). Thyroid iodide uptake remained greater than in the control group after 1 day of MMI withdrawal; however, it decreased to values similar to those found in control animals when MMI was removed 2 or 5 days before they were killed (Fig. 2), despite the increased serum TSH concentration (Table 1). The decreased thyroid uptake of iodide while serum TSH was still high could have been the result of re-establishment of iodine organification 2 days after the withdrawal of MMI. This finding indicates that the content of organified iodine within the thyroid might be an important physiological modulator of NIS activity in the plasma membrane.

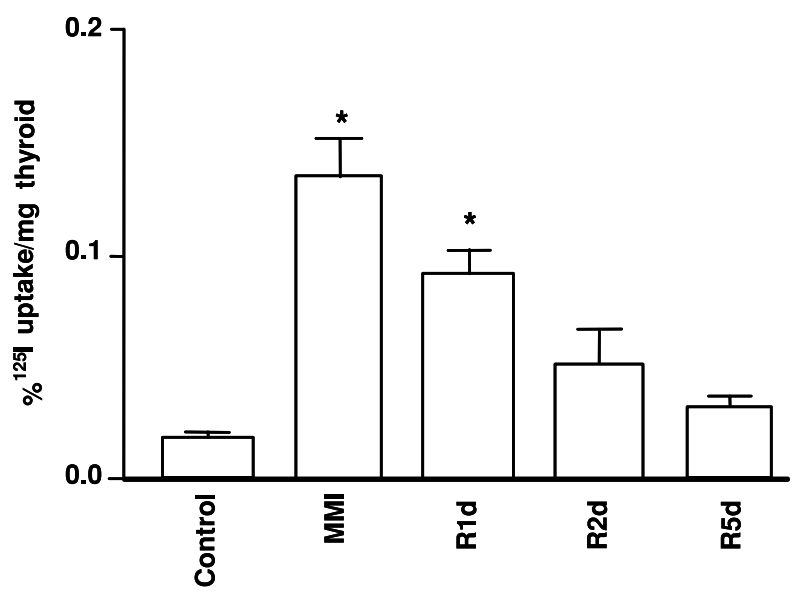

Figure 2 Thyroid radioiodide uptake at $15 \mathrm{~min}$. Control, water available ad libitum; $\mathrm{MMI}, 0.03 \% \mathrm{MMI}$ in drinking water for 21 days; $\mathrm{R} 1 \mathrm{~d}$, as for MMI, followed by 1 day without MMl; R2d, as for MMl, followed by 2 days without MMl; R5d, as for MMI, followed by 5 days without MMI. The thyroids were removed, weighed and the radioactivity measured using a gamma counter and expressed as percentage of the $\left[{ }^{125} \mathrm{I}\right] \mathrm{Nal}$ injected per mg thyroid (control, $n=7$; MMI, $n=7$; R1d without MMI, $n=8$; R2d without MMI, $n=7$; R5d without MMI, $n=8$ ). Results are expressed as the mean \pm S.E.M. of each group. ${ }^{*} P<0 \cdot 05$ compared with control.

TPO iodide oxidation activities were not significantly different among the experimental groups, although a slight increase was detected after 1 day of withdrawal of MMI (Fig. 3). The lack of significance may have been a reflection of the great variability generally found in TPO activity measurements and the high amount of protein

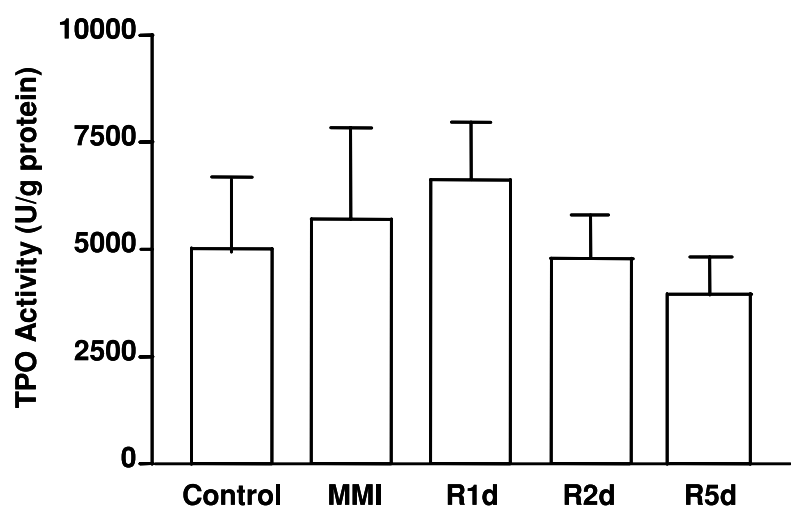

Figure 3 TPO iodide-oxidation activity, measured as previously described. Control, water available ad libitum; MMI, 0.03\% MMI in drinking water for 21 days; $\mathrm{R} 1 \mathrm{~d}$, as for MMI, followed by 1 day without $\mathrm{MMI}$; $\mathrm{R} 2 \mathrm{~d}$, as for $\mathrm{MMI}$, followed by 2 days without $\mathrm{MMI}$; $\mathrm{R} 5 \mathrm{~d}$, as for MMI, followed by 5 days without MMI. Results are expressed as the mean \pm S.E.M. of each group. 
Table 2 Serum total $\mathrm{T}_{4}$ and TSH concentrations (mean \pm S.E.M.) in rats treated with Nal. Concomitant administration of MMI was used to impair thyroid iodine organification as shown

\begin{tabular}{|c|c|c|}
\hline \multirow[b]{2}{*}{ Treatment } & Serum $\mathbf{T}_{\mathbf{4}}(\mu \mathrm{g} / \mathrm{dl})$ & Serum TSH $(\mathrm{ng} / \mathrm{ml})$ \\
\hline & & \\
\hline Control & $3 \cdot 67 \pm 0 \cdot 16$ & $1 \cdot 60 \pm 0 \cdot 14$ \\
\hline 1 day $\mathrm{Nal}$ & $2 \cdot 34 \pm 0 \cdot 32^{*}$ & $2 \cdot 36 \pm 0 \cdot 27$ \\
\hline 6 days $\mathrm{Nal}$ & $4 \cdot 56 \pm 0 \cdot 38$ & $3 \cdot 11 \pm 0 \cdot 32 \ddagger$ \\
\hline 6 days $\mathrm{Nal}+\mathrm{MMI}+\mathrm{T}_{4}$ & $3 \cdot 59 \pm 0 \cdot 27$ & $5 \cdot 55 \pm 1 \cdot 81 \S$ \\
\hline 6 days MMI & $0 \cdot 70 \pm 0 \cdot 08 \dagger$ & $13 \cdot 30 \pm 4 \cdot 41 \dagger$ \\
\hline 6 days $\mathrm{MMI}+\mathrm{T}_{4}$ & $3 \cdot 34 \pm 0 \cdot 46$ & $2 \cdot 42 \pm 0 \cdot 43$ \\
\hline
\end{tabular}

Control, water available ad libitum; 1 day Nal, 0.05\% Nal in the drinking water for 1 day; 6 days Nal, $0.05 \% \mathrm{Nal}$ in the drinking water for 6 days; 6 days $\mathrm{Nal}+\mathrm{MMI}+\mathrm{T}_{4}, 0.05 \% \mathrm{Nal}$ and $0.03 \% \mathrm{MMI}$ in the drinking water for 6 days and $1 \mu \mathrm{g} \mathrm{T}_{4} / 100 \mathrm{~g}$ b.w. s.c. for 5 days, starting 1 day after the beginning of treatment with $\mathrm{MMI}$ and $\mathrm{Nal} ; 6$ days $\mathrm{MMI}, 0.03 \% \mathrm{MMI}$ alone in the drinking water for 6 days; 6 days $\mathrm{MMI}+\mathrm{T}, 0.03 \% \mathrm{MMI}$ in the drinking water for 6 days and $1 \mu \mathrm{g} \mathrm{T}_{4} / 100 \mathrm{~g}$ b.w. s.c. for 5 days, starting 1 day after the beginning of treatment with MMI.

Significantly different values $(P<0 \cdot 05)$ compared with: * ${ }^{*}$ control, 6 days $\mathrm{Na}$ and 6 days $\mathrm{Nal}+\mathrm{MMI}+\mathrm{T}_{4}$; †all groups; łcontrol and 6 days $\mathrm{MMl}$; Sall groups except 6 days $\mathrm{Nal}$.

extracted from goitrous glands. Moreover, in vivo inhibition of TPO as a result of the administration of MMI was maintained at least in part in vitro.

\section{Regulation of NIS activity by iodine}

Administration of $\mathrm{NaI}$ for 1 day significantly decreased serum $\mathrm{T}_{4}$ concentrations; nevertheless, after 6 days of $\mathrm{NaI}$ treatment the serum $\mathrm{T}_{4}$ concentration was normalized, but serum TSH was increased (Table 2). This normalization of the serum $\mathrm{T}_{4}$ concentration after some days of iodine treatment can be attributed to increased concentrations of TSH and escape from the Wolff-Chaikoff effect.

In rats treated with $\mathrm{NaI}$ for 6 days, a significant reduction in the 15-min thyroid iodide uptake was detected despite increased concentrations of serum TSH (Fig. 4), consistent with previous reports that decrement in the expression of NIS is involved in escape from the Wolff-Chaikoff effect (Eng et al. 1999). In contrast, 1 day of treatment with $\mathrm{NaI}$ did not change the 15-min thyroid radioiodide uptake, although NIS mRNA and protein were reported to be significantly decreased by the same treatment in a previous study (Eng et al. 1999).

MMI and $\mathrm{T}_{4}$ were administered in association with the 6-day NaI treatment in order to test the importance of iodine organification on blockade of the NIS by iodine, but without a concomitant increase in serum TSH. As can be seen in Table 2, MMI alone for 6 days significantly decreased serum $\mathrm{T}_{4}$ and increased both serum TSH and 15-min radioiodine uptake (Fig. 4B), but serum $\mathrm{T}_{4}$, serum $\mathrm{TSH}$ and $15-\mathrm{min}$ radioiodine uptake were unchanged when the animals received MMI and $\mathrm{T}_{4}$ (Table 2, Fig. 4B). Compared with the controls, serum TSH was increased in rats given $\mathrm{NaI}+\mathrm{MMI}+\mathrm{T}_{4}$ for 6 days, as it
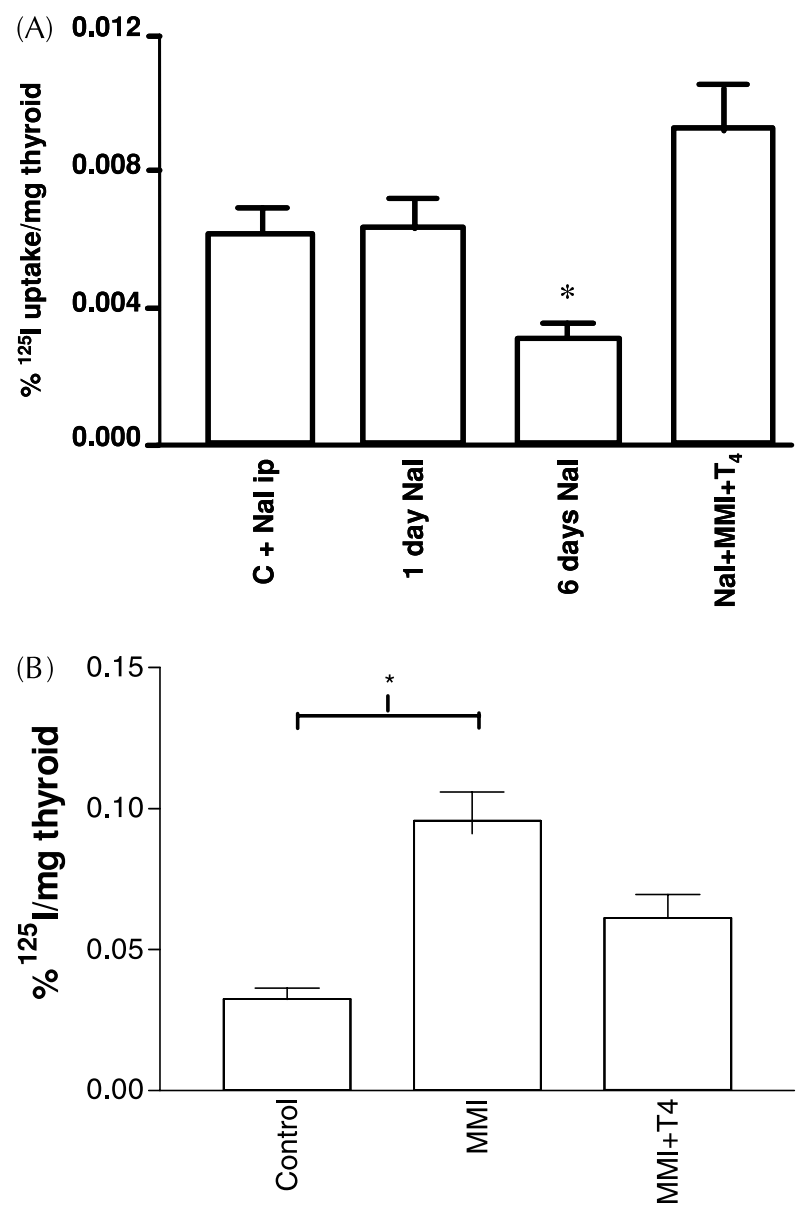

Figure 4 (A) Thyroid iodide uptake at $15 \mathrm{~min}$. Control, water available ad libitum; 1 day Nal, 0.05\% Nal in drinking water for 1 day; 6 days Nal, $0.05 \%$ Nal in drinking water for 6 days; $\mathrm{Nal}+\mathrm{MMI}+\mathrm{T}_{4}, 0.05 \% \mathrm{Nal}$ and $0.03 \% \mathrm{MMI}$ in drinking water for 6 days and $1 \mu \mathrm{g} \mathrm{T} / 100 \mathrm{~g}$ b.w. s.c. for 5 days, starting 1 day after the beginning of treatment with MMI and Nal. Control animals received $2 \mathrm{mg} \mathrm{Nal}$ i.p. $1 \mathrm{~h}$ before the administration of radioiodide in order to achieve similar serum iodide concentrations when compared with 1 day $\mathrm{Nal}, 6$ days $\mathrm{Nal}$ and $\mathrm{Nal}+\mathrm{MMI}+\mathrm{T}_{4}$. The thyroids were removed and weighed and the radioactivity measured using a gamma counter and expressed as percentage of the $\left[{ }^{125} \mathrm{I}\right] \mathrm{Nal}$ injected per mg thyroid (control group, $n=16 ; 1$ day Nal, $n=16 ; 6$ days Nal, $\left.n=20 ; \mathrm{Nal}+\mathrm{MMI}_{4}, n=8\right)$. Results are expressed as the mean \pm S.E.M. of each group. ${ }^{*} P<0.05$ compared with control. (B) Shows the effects of $0.03 \% \mathrm{MMI}$ in drinking water for 6 days and $1 \mu \mathrm{g} \mathrm{T} / 100 \mathrm{~g}$ b.w. s.c. for 5 days in comparison to $0.03 \% \mathrm{MMI}$ in drinking water for 6 days (MMI) alone.

was also in the animals given $\mathrm{NaI}$ for 6 days (Table 2); however, the 15-min radioiodine uptake was similar to that in the control group, showing that iodine organification is essential for the blockade of iodide transport produced by iodine overload (Fig. 4A).

TPO iodide oxidation activity was decreased, although not significantly, in the animals that received $\mathrm{NaI}$ for 


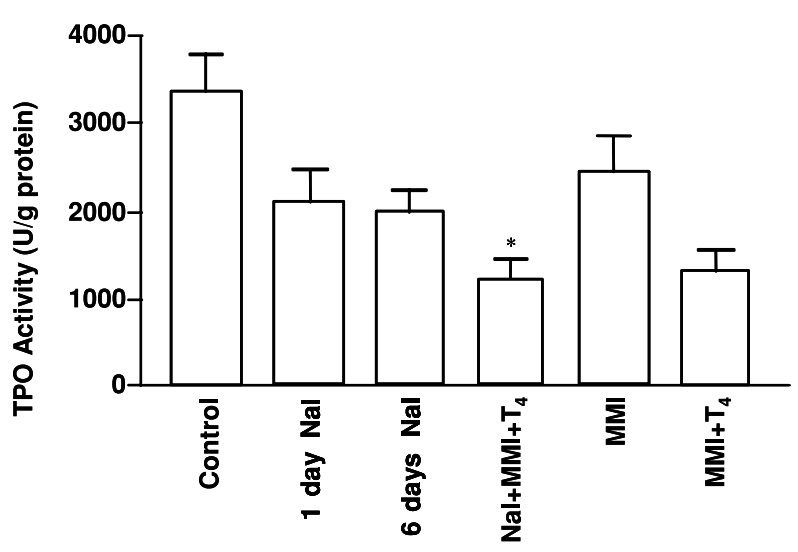

Figure 5 TPO iodide-oxidation activity, measured as previously described. Control, water available ad libitum; 1 day Nal, 0.05\% $\mathrm{Nal}$ in drinking water for 1 day; 6 days $\mathrm{Nal}, 0 \cdot 05 \% \mathrm{Nal}$ in drinking water for 6 days; $\mathrm{Nal}+\mathrm{MMI}+\mathrm{T}_{4}, 0.05 \% \mathrm{Nal}$ and $0.03 \% \mathrm{MMI}$ in drinking water for 6 days and $1 \mu \mathrm{g} \mathrm{T} / 100 \mathrm{~g}$ b.w. s.c. for 5 days, starting 1 day after the beginning of treatment with $\mathrm{MMI}$ and $\mathrm{Nal}$; $\mathrm{MMI}, 0.03 \% \mathrm{MMI}$ in drinking water for 21 days; $\mathrm{MMI}+\mathrm{T}_{4}, 0.03 \%$ $\mathrm{MMI}$ in the drinking water for 6 days and $1 \mu \mathrm{g} \mathrm{T} / 100 \mathrm{~g}$ b.w. s.c. for 5 days, starting 1 day after the beginning of treatment with MMI. The results are expressed in $\mathrm{U} / \mathrm{g}$ protein (control group, $n=21 ; 1$ day $\mathrm{Nal}, n=16 ; 6$ days $\mathrm{Nal}, n=17 ; \mathrm{Nal}+\mathrm{MMI}+\mathrm{T}_{4}, n=6$; MMI, $n=5 ; \mathrm{MMI}_{4}, n=2$ ). Results are expressed as the mean \pm S.E.M. of each group. ${ }^{*} P<0.05$ compared with control.

6 days and was significantly decreased in the group that received $\mathrm{NaI}+\mathrm{MMI}+\mathrm{T}_{4}$ for 6 days (Fig. 5).

\section{Discussion}

Two factors are determinants of thyroid iodine content: transport of iodide through the NIS and iodine organification at the apical membrane. The 15-min iodide uptake measurement is not influenced by the previous administration of MMI, a drug that inhibits organification. In contrast, the 2-h iodide uptake decreases by almost $90 \%$ when MMI is administered before iodide, showing that, at this time, iodine organification activity is the main determinant of the thyroid radioiodine content. Thus the radioiodine content measured after $15 \mathrm{~min}$ of iodide administration can be used as an efficient measure of the basolateral transport of iodide through the NIS. Here, we have demonstrated the rapid modulation of NIS activity in the plasma membrane of thyrocytes with a new approach using an early evaluation of thyroid uptake of radioiodide (15 min after the administration of radioiodide).

Animals treated with MMI for 21 days showed a significantly increased uptake of 15-min radioiodine, which can be attributed to the high serum TSH concentration. When MMI was removed 1 day before the animals were killed, the serum TSH concentration was still high and NIS activity decreased, although not significantly. Two days after withdrawal of MMI, the high con- centrations of TSH were maintained; nevertheless, the 15-min iodide uptake was significantly decreased when compared with that of rats treated with MMI for 21 days. The lower NIS activity in the presence of still increased serum TSH indicates that TPO had resumed its activity, leading to the production of the organified iodine compound, which is responsible for the inhibition of iodide transport through the basolateral membrane of the thyrocyte. Serum $\mathrm{T}_{4}$ also began to increase 2 days after the withdrawal of MMI, and reached normal values after 5 days without MMI, confirming the early resumption of TPO activity after MMI withdrawal.

Administration of $\mathrm{NaI}$ for 6 days led to a significant reduction in NIS activity, despite high serum TSH concentrations. However, TPO organification activity seems to be important for such an inhibition to occur, as the same treatment was unable to reduce radioiodide transport when TPO activity was concomitantly inhibited by the administration of MMI. These results support the idea that organified iodine, and not iodide itself, is responsible for the inhibition of the basolateral transport of iodide, as previously suggested (Grollman et al. 1986).

Thyroid uptake of radioiodide was not decreased after 1 day of $\mathrm{NaI}$ treatment, which suggests that the NIS activity is blocked only after a longer period of treatment with iodide. Our results are consistent with data reported by Eng et al. (1999) showing a decrease in NIS mRNA and protein 6 days after the beginning of $\mathrm{NaI}$ treatment. However, whereas we found no change in the in vivo NIS activity, Eng et al. (1999) detected decreased levels of NIS mRNA and protein as early as after 1 day of $\mathrm{NaI}$ treatment. Therefore, although the expression of NIS could be decreased by iodide after 1 day of iodine overload, NIS activity in the plasma membrane seems to be maintained, again indicating that modulation of the expression of NIS can be different in some aspects from the regulation of its subcellular distribution. In fact, Riedel et al. (2001) showed that NIS protein is found both in the plasma membrane and in intracellular vesicles. Therefore, alterations in NIS protein content may not always correlate with modifications in iodide transport activity through the thyrocyte plasma membrane, and vice versa.

TPO iodide oxidation activity was not significantly different among the groups studied, which is consistent with the great variability found in measurements of this enzyme activity. However, a decrease in TPO was found in rats treated with $\mathrm{NaI}$ for 6 days, with or without MMI, indicating that iodine organification seems not to be essential for the inhibition of TPO biosynthesis by iodine overload in vivo. The findings of recent studies support the idea that blockade of iodine organification during the Wolff-Chaikoff effect is mainly attributable to the inhibition of NADPH oxidase activity leading to decreased generation of hydrogen peroxide (Cardoso et al. 2001, Morand et al. 2003), and is not secondary to TPO inhibition as previously suggested (Pommier et al. 1973). 
The weak regulation of TPO activity detected might be attributable to the fact that TPO is less modulated than is NIS activity. In a previous study (Cardoso et al. 2002), we found that expression and activity of TPO protein were significantly decreased only after a longer period of treatment with iodine (10-15 days rather than 7 days) in toxic diffuse goitres. Accordingly, expression of NIS mRNA was shown to be much more affected by iodine treatment than was expression of TPO mRNA in primary cultures of porcine thyrocytes (Morand et al. 2003). Further studies are needed for better evaluation of the effects of the administration of iodine on expression of the TPO gene.

Serum concentrations of $\mathrm{T}_{4}$ were slightly greater in rats treated with $\mathrm{NaI}$ for 6 days in comparison with those in the control group, although this increase was not statistically significant in the present study. This increase was probably a consequence of increased TSH concentrations, which were significantly greater in this group than in control groups. It is important to point out that animals treated with $\mathrm{NaI}$ for 6 days showed significantly decreased radioiodine uptake although concentrations of TSH were increased, which reinforces the importance of thyroid autoregulation in the control of NIS activity. Eng et al. (1999) also showed increased serum $T_{4}$ concentrations in animals treated with $\mathrm{NaI}$ for 6 days; however, the concentrations of TSH were not significantly increased in that study. Thus our findings corroborate previous reports that decreased NIS activity is implicated in escape from the Wolff-Chaikoff effect.

Using this novel approach of early (15-min) measurement of iodide uptake, we showed that not only are high doses of iodine able to block NIS activity, but also thyroid iodine content within the physiological range modulates NIS activity. Moreover, regulation of NIS activity by iodide can be more important than regulation by TSH, as rats with high TSH concentrations showed a decrease in NIS activity when their thyroid pool of organic iodine increased. Taken together, our data reinforce the concept that a low-iodine diet before the administration of diagnostic or therapeutic doses of radioiodine is essential for increasing the ability of the thyroid gland to take up iodide.

\section{Acknowledgements}

We are grateful for the technical assistance of Norma Lima de Araújo Faria, Advaldo Nunes Bezerra and Wagner Nunes Bezerra. The authors declare that there is no conflict of interest that would prejudice the impartiality of this scientific work.

\section{Funding}

This work was supported by grants from Fundação Carlos Chagas Filho de Amparo à Pesquisa do Estado do Rio de Janeiro (FAPERJ), Conselho Nacional de Desenvolvimento Científico e Tecnológico (CNPq) and Howard Hughes Medical Institute (Departmental sharing of grant no. 55003669). Andrea C F Ferreira and Norma $\mathrm{L}$ A Faria were recipients of fellowships from $\mathrm{CNPq}$ during the study.

\section{References}

Berson SA \& Yalow RS 1955 The iodide trapping and binding functions of the thyroid. Journal of Clinical Investigation 34 186-204.

Bradford MM 1976 A rapid and sensitive method for the quantitation of microgram quantities of protein utilizing the principle of protein-dye binding. Annals of Biochemistry 72 248-254.

Braverman LE \& Ingbar SH 1963 Changes in thyroidal function during adaptation to large doses of iodide. Journal of Clinical Investigation 42 1216-1231.

Cardoso LC, Martins DC, Figueiredo MD, Rosenthal D, Vaisman M, Violante AH \& Carvalho DP $2001 \mathrm{Ca}(2+) /$ nicotinamide adenine dinucleotide phosphate-dependent $\mathrm{H}_{2} \mathrm{O}_{2}$ generation is inhibited by iodide in human thyroids. Journal of Clinical Endocrinology and Metabolism 86 4339-4343.

Cardoso LC, Martins DC, Campos DV, Santos LM, Correa da Costa VM, Rosenthal D, Vaisman M, Violante AH \& Carvalho DP 2002 Effect of iodine or iopanoic acid on thyroid $\mathrm{Ca} 2+/ \mathrm{NADPH}-$ dependent $\mathrm{H}_{2} \mathrm{O}_{2}$-generating activity and thyroperoxidase in toxic diffuse goiters. European Journal of Endocrinology 147 293-298.

Carvalho DP, Rego KGM \& Rosenthal D 1994 Thyroid peroxidase in dyshormonogenetic goiters with organification and thyroglobulin defects. Thyroid 4 421-426.

Chung JK 2002 Sodium iodide symporter: its role in nuclear medicine. Journal of Nuclear Medicine 43 1188-1200.

Dai G, Levy O \& Carrasco N 1996 Cloning and characterization of the thyroid iodide transporter. Nature 379 458-460.

Dohan O, Baloch Z, Banrevi Z, Livolsi V \& Carrasco N 2001 Rapid communication: predominant intracellular overexpression of the $\mathrm{Na}(+) / \mathrm{I}(-)$ symporter (NIS) in a large sampling of thyroid cancer cases. Journal of Clinical Endocrinology and Metabolism 86 2697-2700.

Dohan O, Vieja A, Paroder V, Riedel C, Artani M, Reed M, Ginter CS \& Carrasco N 2003 The sodium/iodide symporter (NIS): characterization, regulation, and medical significance. Endocrine Reviews 24 48-77.

Eng PHK, Cardona GR, Fang SL, Previti M, Alex S, Carrasco N, Chin WW \& Braverman LE 1999 Escape from the acute Wolff Chaikoff effect is associated with a decrease in thyroid sodium/iodide symporter messenger ribonucleic acid and protein. Endocrinology 140 3404-3410.

Eskandari S, Loo DDF, Dai G, Levy O, Wright EM \& Carrasco N 1997 Thyroid $\mathrm{Na}^{+} / \mathrm{I}^{-}$symporter - mechanism, stoichiometry, and specificity. Journal of Biological Chemistry 272 27230-27238.

Fish WA, Carlin H \& Hickey FC 1952 The thyroidal uptake, retention and iodine pool in rats under controlled iodide diet. Endocrinology 51 282-292.

Grollman EF, Smolar A, Ommaya A, Tombaccini D \& Santisteban P 1986 Iodine suppression of iodide uptake in FRTL-5 thyroid cells. Endocrinology 118 2477-2482.

Heufelder AE, Morgenthaler N, Schipper ML \& Joba W 2001 Sodium iodide symporter-based strategies for diagnosis and treatment of thyroidal and nonthyroidal malignancies. Thyroid 11 839-847.

Kaminsky SM, Levy O, Salvador C, Dai G \& Carrasco N 1994 $\mathrm{Na}^{+} / \mathrm{I}^{-}$symport activity is present in membrane vesicles from thyrotropin-deprived non- $\mathrm{I}^{-}$transporting cultured thyroid cells. PNAS 91 3789-3793. 
Morand S, Chaaraoui M, Kaniewski J, Deme D, Ohayon R, Noel-Hudson MS, Virion A \& Dupuy C 2003 Effect of iodide on nicotinamide adenine dinucleotide phosphate oxidase activity and Duox2 protein expression in isolated porcine thyroid follicles. Endocrinology 144 1241-1248.

Moura EG, Ramos CF, Nascimento CC, Rosenthal D \& Breitenbach MM 1987 Thyroid function in fasting rats: variations in $131 \mathrm{I}$ uptake and transient decrease in peroxidase activity. Brazilian Journal of Medical and Biological Research 20 407-410.

Moura EG, Rosenthal D \& Carvalho-Guimarães DP 1989 Thyroid peroxidase activity in human nodular goiters. Brazilian Journal of Medical and Biological Research 22 31-39.

Nakashima T \& Taurog A 1978 Improved assay procedures for thyroid peroxidase; applications to normal and adenomatous human thyroid tissue. Clinica Chimica Acta 83 129-140.

Panneels V, Van Sande J, Van den Bergen H, Jacoby C, Braekman JC, Dumont JE \& Boeynaems JM 1994 Inhibition of human thyroid adenylyl cyclase by 2-iodoaldehydes. Molecular and Cellular Endocrinology 106 41-50.

Panneels V, Macours P, Van den Bergen H, Braekman JC, Van Sande J \& Boeynaems JM 1996 Biosynthesis and metabolism of 2-iodohexadecanal in cultured dog thyroid cells. Journal of Biological Chemistry 271 23006-23014.

Pommier J 1978 Solubilization, purification, propriétés moleculaires et mécanisme d'action de la peroxidase thyroidienne. In: Méthodologie Experimentale en Physiologie et Physiopathologie Thyroidienne, pp 137-148. Eds R Hornek \& J Nunez. Paris: INSERM.

Pommier J, Deme D \& Nunez J 1973 Effect of iodide concentration on thyroxine synthesis catalysed by thyroid peroxidase. European Journal of Biochemistry 37 406-414.

Price DJ \& Sherwin JR 1986 Autoregulation of iodide transport in the rabbit: absence of autoregulation in fetal tissue and comparison of maternal and fetal thyroid iodination products. Endocrinology 119 2547-2552.

Riedel C, Levy O \& Carrasco N 2001 Post-transcriptional regulation of the sodium/iodide symporter by thyrotropin. Journal of Biological Chemistry 276 21458-21463.
Smanik PA, Liu Q, Furminger TL, RyuK, Xing S, Mazzaferri EL \& Jhiang SM 1996 Cloning of the human sodium iodide symporter. Biochemistry and Biophysical Research Communication 226 339-345.

Socolow EL, Dunlap D, Sobel RA \& Ingbar SH 1968 A correlative study of the effect of iodide administration in the rat on thyroidal iodide transport and organic iodine content. Endocrinology $\mathbf{8 3}$ 737-743.

Spitzweg C \& Morris JC 2001 Approaches to gene therapy with sodium/iodide symporter. Experimental and Clinical Endocrinology 109 56-59.

Taurog A 2000 Hormone synthesis: thyroid iodine metabolism. In The Thyroid: A Fundamental and Clinical Text, edn 8, pp 61-85. Eds LE Braverman \& RD Utiger. Philadelphia: Lippincott Williams \& Wilkins.

Tonacchera M, Viacava P, Agretti P, de Marco G, Perri A, di Cosmo C, de Servi M, Miccoli P, Lippi F, Naccarato AG, Pinchera A, Chiovato L \& Vitti P 2002 Benign nonfunctioning thyroid adenomas are characterized by a defective targeting to cell membrane or a reduced expression of the sodium iodide symporter protein. Journal of Clinical Endocrinology and Metabolism 87 352-357.

Uyttersprot N, Pelgrims N, Carrasco N, Gervy C, Maenhaut C, Dumont JE \& Miot F 1997 Moderate doses of iodide in vivo inhibit cell proliferation and the expression of thyroperoxidase and $\mathrm{Na}+/ \mathrm{I}-$ symporter mRNAs in dog thyroid. Molecular and Cellular Endocrinology 131 195-203.

Van Sande J, Cochaux P \& Dumont JE 1985 Further characterization of the iodide inhibitory effect on the cyclic AMP system in dog thyroid slices. Molecular and Cellular Endocrinology 40 181-192.

Van Sande J, Massart C, Beauwens R, Schoutens A, Costagliola S, Dumont JE \& Wolff J 2003 Anion selectivity by the sodium iodide symporter. Endocrinology 144 247-252.

Wolff J \& Chaikoff IL 1948 Plasma inorganic iodide as a homeostatic regulator of thyroid function. Journal of Biological Chemistry 174 $555-564$.

Received in final form 10 September 2004

Accepted 16 September 2004 